\title{
VAŽNOST STRANIH RADNIKA ZA RAZVOJ GOSPODARSTVA U VARAŽDINSKOJ ŽUPANIJI
}

Povećanim migracijama u Republiku Hrvatsku, povećava se i broj stranih radnika koji su dostupni na tržištu rada. Varaždinska županija posljednjih godina bilježi značajan rast stranih radnika u raznim industrijama. Sekundarnim istraživanjem provedena je analiza broja stranih radnika u 2019. i 2020. godini koji su trenutno prijavljeni na području Varaždinske županije. Provedenim intervjuima s poduzećima koje posluju u prehrambenoj, obućarskoj, tekstilnoj i farmaceutskoj industriji prikupljeni su kvalitativni podaci o važnosti stranih radnika kako za sama poduzeća tako i za gospodarstvo Varaždinske županije. Istraživanje daje odgovore na pitanja o dugoročnoj potrebi za stranim radnicima, njihovom uključivanju u poslovne procese, moguće barijere s kojima se suočavaju (jezične i tehnološke), ali i viđenje problema njihovog uključivanja u lokalnu zajednicu u vidu predrasuda, kulture i jezika.

Ključne riječi: inkluzija u društvo; radna snaga; strani radnici; Varaždinska županija.

\section{UVOD}

Česti novinski natpisi o novoj radnoj snazi u Varaždinskoj županiji dovode do pitanja o potrebi navedenih radnika te zašto se upravo takvi radnici zapošljavaju. Kako navedeni radnici u zadnje vrijeme dolaze iz dalekih zemalja kao što su Nepal i Filipini, postavlja se pitanje kako to da se poslodavci odlučuju upravo za njih, ali i kako se isti uklapaju u našu kulturu i koliko se mogu sporazumijevati s poslodav cem s obzirom na jezične i kulturološke razlike. Mnoge novine i portali, kao što su 
regionalni.hr, Večernji list, Varaždinske vijesti, eMeđimurje, danica.hr, Jutarnji list, Međimurske novine i moj-posao pisali su o velikom priljevu stranih radnika iz dalekih zemalja te iznosili primjere poduzeća koje zapošljavaju strane radnike, ali i priče radnika koji su došli raditi u Varaždinsku županiju.

Cilj rada je utvrditi važnost stranih radnika u Varaždinskoj županiji te razloge zapošljavanja istih. Kako bi se postigao cilj, postavljena su tri istraživačka pitanja na koja će se dobiti odgovori pomoću primarnog kvalitativnog i kvantitativnog istraživanja:

1. Postoji li dugoročna potreba za stranim radnicima u Varaždinskoj županiji?

2. Koji su problemi uključivanja stranih radnika u poslovne procese?

3. Koji su problemi uključivanja stranih radnika u lokalnu zajednicu?

Do sada je provedeno svega nekoliko istraživanja u Republici Hrvatskoj koja su u nekom dijelu istraživala strane radnike. Božić, Kuzmanović i Barda su 2013. godine proveli istraživanje na temu „Strani radnici u Hrvatskoj: porijeklo, status, orijentacije" koje je bilo usmjereno na rasvjetljavanje socijalnog položaja imigranata, demografske karakteristike, geografsko podrijetlo, način i razloge dolaska, diskriminaciju i sl. ${ }^{1}$ U 2012. godini Čačić-Kumpes, Gregurović i Kumpes proveli su istraživanje na temu „Migracija, integracija i stavovi prema imigrantima u Hrvatskoj" koje je provedeno prije ulaska Hrvatske u Europsku uniju te je utemeljeno na pretpostavkama promjene migracijskog obrasca. Navedenim istraživanjem je pretpostavljeno da će ulaskom Hrvatske u EU doći do povećanog dolaska stranih radnika. Također su ispitani stavovi, na uzorku od 1300 punoljetnih građana Republike Hrvatske, prema stranim radnicima, njihovom utjecaju na kulturu, vrijednosti hrvatskog društva i društvene distance prema njima. ${ }^{2}$ Šijaković Ana je u 2018. i 2019. proučavala sigurnost i strane radnike. Predavanje na temu „Sigurnost i zaštita zdravlja stranih radnika - uloga stručnjaka zaštite na radu“ proučava angažman stručnjaka zaštite na radu u izgradnji sigurnog okruženja te integraciju stranih radnika iz koje proizlazi povećan rizik po zdravlje. $\mathrm{U}$ samostalnom radu

1 S. BOŽIĆ, B. KUZMANOVIĆ, V. BARADA (2013), „Strani radnici u Hrvatskoj: porijeklo, status, orijentacije“, Migracijske i etničke teme, 29 3). Dostupno dana 2. studenoga 2020. na: https:// hrcak.srce.hr/ index.php?show=clanak\&id_clanak_jezik=174184.

2 J. ČAČIĆ-KUMPES, S. GREGUROVIĆ i J. KUMPES, (2012). "Migracija, integracija i stavovi prema imigrantima u Hrvatskoj", Revija za sociologiju, 42(3), str. 305-336. Dostupno dana 9. studenoga 2020. na: https://doi.org/10.5613/rzs.42.3.3.

3 I. KRIŠTO, C. KOVAČ, A. ŠIJAKOVIĆ, (2018.), "Sigurnost i zaštita zdravlja stranih radnika - uloga stručnjaka zaštite na radu", 13th INTERNATIONAL CONFERENCE MANAGEMENT AND SAFETY, CONFERENCETHEME:PROJECTMANAGEMENTANDSAFETYPROGRAMCYCLE:MODERNMANAGE MENTCONCEPTSANDSAFETY/Vesna Nikolić,Chair of the International ProgramCommitteeMembers of the International Program Committee (ur.). Čakovec, Croatia: The European Society of Safety Engineers. 34,12. 
Šijaković se bavi temom „Zaštita na radu i strani radnici u RH“ u kojoj se poziva na Zakon o zaštiti na radu te zapošljavanje stranih radnika i njihovu kompatibilnost sa Zakonima u Republici Hrvatskoj. Posljednje istraživanje je od autora Ferjanić Hodak, Kesar i Matečić koji proučavaju strane radnike i njihov utjecaj na hotelsku industriju. Iz prikazanih dosadašnjih istraživanja vidljivo je kako još niti jedan autor nije proučavao strane radnike u Varaždinskoj županiji, ali nije niti proučavao konkretan broj radnika, države iz kojih dolaze, zadovoljstvo poslodavaca s istima, njihovu prilagodbu na posao i integraciju u društvu, što sve je prikazano ovim istraživanjem.

\section{RAD STRANACA}

Radnu snagu neke države čine sve osobe koje su zaposlene i one koje aktivno traže posao. ${ }^{6}$ Prema Zakon o radu ${ }^{7}$ u Republici Hrvatskoj to su osobe starije od 15 godina koje ne pohađaju obvezno osnovno obrazovanje. Prema Pravilniku o aktivnom traženju posla i raspoloživosti za rad $^{8}$ aktivno traženje posla obuhvaća sudjelovanje nezaposlene osobe u savjetovanju, individualnim konzultacijama, grupnom informiranju, radionicama za razvoj vještina upravljanja karijerom, definiranju i provedbi aktivnosti i ciljeva Profesionalnog plana, definiranju i provedbi aktivnosti i ciljeva Sporazuma o uključivanju na tržište rada, postupku profesionalne selekcije, postupku profesionalnog usmjeravanja i drugim aktivnostima u svrhu pripreme za zapošljavanje. U Republici Hrvatskoj državljanin treće zemlje može raditi s ozvolom za boravak i rad ili potvrde o prijavi rada samo za poslove za koje je izdana i kod poslodavca s kojim je zasnovao radni odnos. Dozvola za boravak i rad dobiva se, izuzev ispunjenih uvjeta, temeljem ugovora o radu (pisane potvrde o sklopljenom ugovoru ili odgovarajući dokaz o radu), dokaza o stečenoj obrazovnoj

$4 \quad$ A. ŠIJAKOVIĆ (2019), "Zaštita na radu i strani radnici u RH", Sigurnost 61 (4). 391-394.

5 D. FERJANIĆ HODAK, O. KESAR, I. MATEČIĆ (2019) The influence of foreign labour force on service provision and hotel guests' experience - the case of coastal Croatia. Tourism in Southern and Eastern Europe, Vol. 5, pp. 275-289.

6 Đuro BENIĆ, 2011. Uvod u ekonomiju, Školska knjiga, Zagreb.

7 Zakon o radu. NN 93/14, 127/17, 98/19. Dostupno dana 5. studenoga 2020. na: https://www. zakon.hr/z/307/Zakon-o-radu.

8 Pravilnik o aktivnom traženju posla i raspoloživosti za rad. NN 28/19. Dostupno dana 28. rujna 20-21. na: https://narodne-novine.nn.hr/clanci/sluzbeni/2019_03_28_586.html. 
kvalifikaciji i osposobljenosti te dokaza o registraciji trgovačkog društva, obrta i slično u Republici Hrvatskoj. ${ }^{9}$

Zbog rasta ekonomije i povećanog iseljavanja, Republika Hrvatska je prošlih godina konstantno povećavala kvote za uvoz radne snage..$^{10} \mathrm{U} 2019$. godini ta kvota je iznosila 55.100 dozvola za boravak i rad, a 2020. iznosi 78.470 dozvola za boravak i rad. S obzirom na situaciju uzrokovanu pandemijom COVID-19, odnosno zatvaranje granica, ograničenja putovanja i općenito smanjenje zaposlenih, u 2020. godini do 27. studenog je iskorišteno samo 37.133 (47,32\%) dozvola za boravak i rad dok je na taj dan bilo u postupku dobivanja 5.705 dozvole za boravak i rad. Najviše dodijeljenih dozvola za boravak i rad u 2020. godini je dodijeljeno u djelatnosti Graditeljstvo, njih 22.331 do 27. studenoga i njih 3.689 koje su još u postupku, odnosno kvota je ispunjena u iznosu od 78,14\%. ${ }^{11}$ Djelatnost Graditeljstva zapošljava najviše stranih radnika, a ta djelatnost ima „Iznimno naporan, nesiguran i uglavnom slabo plaćen rad (u usporedbi s tercijarnim sektorom čak i u Hrvatskoj) koji često traži i spremnost na mobilnost ovisno o području rada tvrtke, uza stalnu izloženost vremenskim prilikama, nije posebno privlačan hrvatskim radnicima., ${ }^{12}$

Migranti u Hrvatskoj se susreću s problemom nezaposlenosti, nepoznavanja jezika, diskriminacije na tržištu rada te nepriznavanje kvalifikacije, a uz to i otežan pristup programima prekvalifikacije. Centar za mirovne studije navodi da kod slučaja da migranti dobiju posao, oni su najčešće slabije plaćeni te nisu u skladu s kvalifikacijama migranata, a često su u neadekvatnim radnim uvjetima i krše radnička prava. ${ }^{13}$

${ }^{9}$ Središnji državni portal. Moja uprava. Pravna država i sigurnost. Strani radnici u RH. Rad stranaca. Dostupnodana8.studenoga2020.na:https://gov.hr/moja-uprava/pravna-drzava-i-sigurnost/strani-drzavljani-u-rh/rad-stranaca/1724.

${ }^{10}$ Novi list. Nikad manje stranih radnika u Hrvatskoj: Neiskorištena 53.931 radna dozvola. Dostupno dana 5. studenoga 2020. na: https://www.novilist.hr/novosti/hrvatska/nikad-manje-stranih-radni-ka-u-hrvatskoj-neiskoristena-53-931-radna-dozvola/?meta_refresh=true.

${ }^{11}$ Ministarstvo unutarnjih poslova. Statistika. Iskorištenost godišnje kvote za 2020. na dan 27. studenoga 2020. Dostupno dana 28. studenoga 2020. na: https://mup.gov.hr/UserDocsImages/ statistika/2020/Kvote/ISKORISTENOST-GODISNJE-KVOTE-ZA-2020-NA-DAN-27-11-2020.pdf.

${ }^{12}$ Božić, S., Kuzmanović, B., Barada, V. (2013), "Strani radnici u Hrvatskoj: porijeklo, status, orijentacije", Migracijske i etničke teme, 29 3). Dostupno dana 2. studenoga 2020 na: https://hrcak. srce.hr/index.php?show=clanak\&id_clanak_jezik=174184.

${ }^{13}$ Lider media. CMS upozorava na teškoće u zapošljavanju migranata u Hrvatskoj. Dostupno dana 2. studenoga 2020. na: https://lider.media/aktualno/cms-upozorava-na-teskoce-u-zaposljavanju-migranata-u-hrvatskoj-33100 


\section{PRIKAZ REZULTATA ISTRAŽIVANJA}

U svrhu istraživanja provedeno je primarno istraživanje analize broja stranih radnika u 2019. i 2020. godini prema podacima koji su dobiveni od Policijske uprave Varaždinske. Također je provedeno kvalitativno istraživanje pomoću intervjua s vodećim osobama u pet poduzeća koja zapošljavaju strane radnike. Izabrana poduzeća su namjerno izabrana u uzorak, jer zapošljavaju najveći udio stranih radnika u Varaždinskoj županiji. Navedena poduzeća posluju u tekstilnoj, obućarskoj, prehrambenoj i farmaceutskoj industriji.

Analizom podataka dobivenih od Policijske uprave Varaždinske utvrđeno je da je u 2019. godini u Varaždinskoj županiji registrirano 1480 novih zapošljavanja stranih radnika, 562 radnika su tražila produljenje zaposlenja, a 15 ih je zaposleno sezonski. Od 1. siječnja 2020. do 1. srpnja 2020. godine u Varaždinskoj županiji registrirano je 1053 nova zapošljavanja stranih radnika, 289 ih je tražilo produljenje zaposlenja, a samo jedan radnik je zaposlen sezonski. Navedeni podaci su prikazani u grafikonu 1 te bi se iz istoga moglo zaključiti kako se povećani trend zapošljavanja stranih radnika nastavlja jer je broj novozaposlenih dosegnuo 71,15\% ukupnog broja u samo 6 mjeseci ove godine.

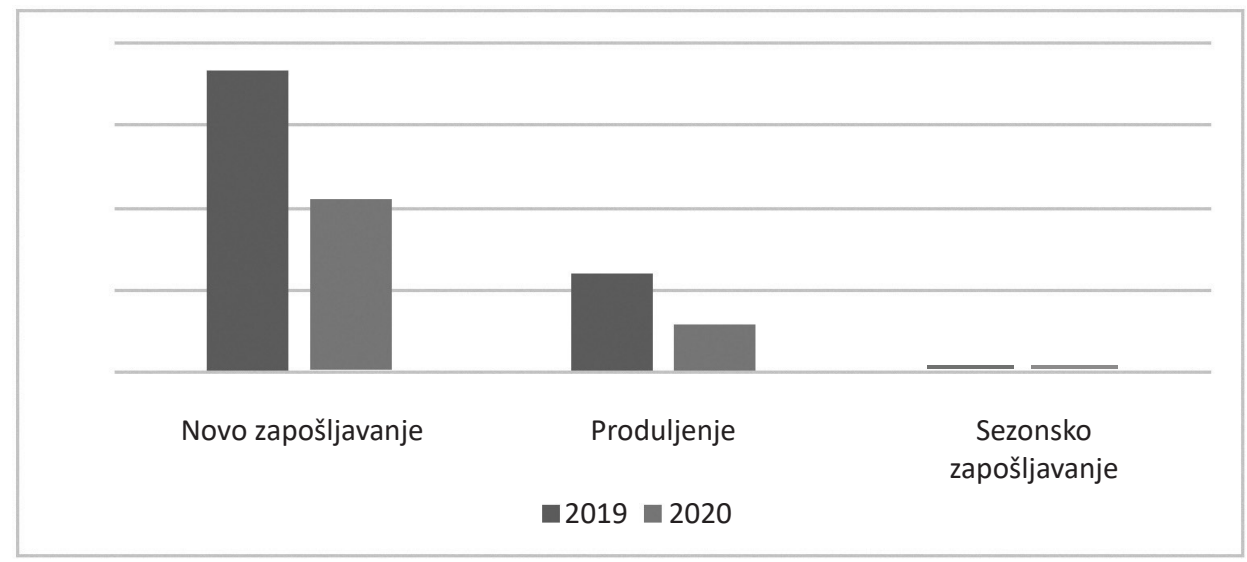

Grafikon 1. Broj stranih radnika u Varaždinskoj županiji Izvor: vlastita izrada prema podacima Policijske uprave Varaždinske 
Grafikon 2. daje prikaz Broja stranih radnika u Varaždinskoj županiji prema državljanstvu u 2019. godini. Strani radnici dolaze iz mnogih zemalja, no očekivano najviše ih je iz Bosne i Hercegovine te iz Srbije s obzirom da su to najbliže zemlje, kako geografski tako i kulturno i jezično. Ukupan broj novozaposlenih iz Bosne i Hercegovine iznosio je 635, a broj osoba koje su tražila produljenje zaposlenja u istoj godini iznosio je 192, dok je broj državljana iz Srbije koji čine novozaposlene iznosio je 499, a oni koji su tražili produljenje je 82. Ono što je danas sve češće jest zapošljavanje stranih radnika iz dalekih zemalja, a kako je vidljivo iz grafikona u 2019. godine najviše je stranih radnika iz Nepala, a nešto manje iz Vijetnama. Broj novozaposlenih iz Nepala iznosio 310 te oni čine novu radnu snagu u Varaždinskoj županiji.

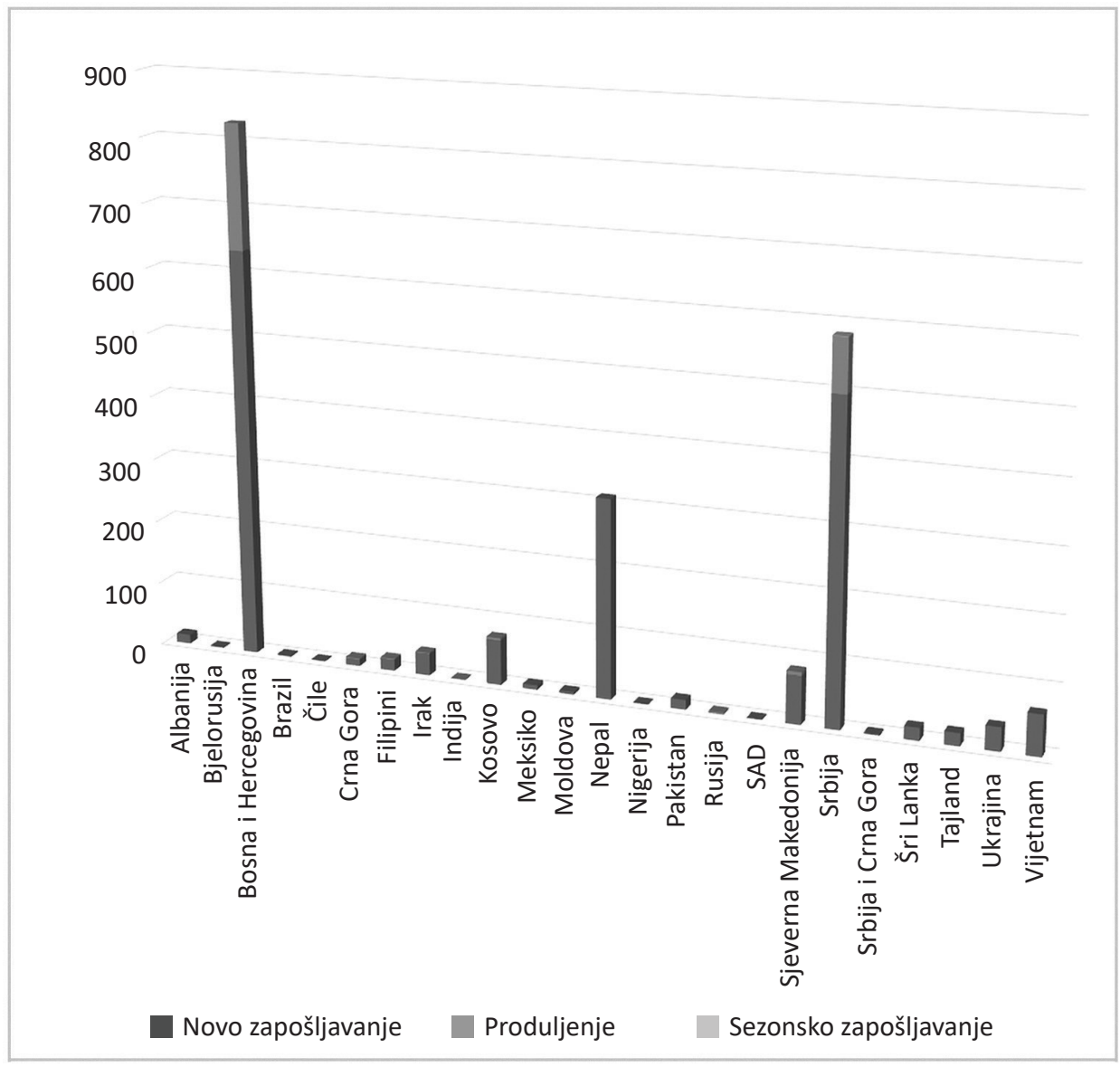

Grafikon 2. Broj stranih radnika u Varaždinskoj županiji prema državljanstvu od 1. siječnja 2019. do 31. prosinca 2019. godine Izvor: vlastita izrada autora prema podacima Policijske uprave Varaždinske 
Jednako kao i u 2019. godini, u prvoj polovici 2020. godine najveći broj novozaposlenih stranih radnika, kao i onih koji su tražili produljenje zaposlenja dolaze iz Bosne i Hercegovine i Srbije, dok ih slijede radnici iz Nepala, Vijetnama, Ukrajine i s Filipina, što je vidljivo iz grafikona 3.

Ukupan broj novih zapošljavanja osoba iz Bosne i Hercegovini u prvoj polovici 2020. godine iznosio je 329 , dok je broj osoba koje su tražile produljenje iznosio 187. Interesantno je da je u prvoj polovici 2020. godine broj novozaposlenih iz Nepala iznosio 129 što je 41,61\% od ukupnog broja novozaposlenih iz iste zemlje u 2019. godini. Što se produljenja tiče, broj osoba iz Nepala kojima je produljeno zaposlenje iznosio je 187, dok godinu prije nitko nije tražio produljenje, jer u 2018. godini još uvijek nije bilo registriranih novozaposlenih osoba iz Nepala. Broj novozaposlenih osoba iz Vijetnama iznosio je 35, dok je iz Ukrajine broj Novozaposlenih iznosio 44, a iz Tajlanda 11.

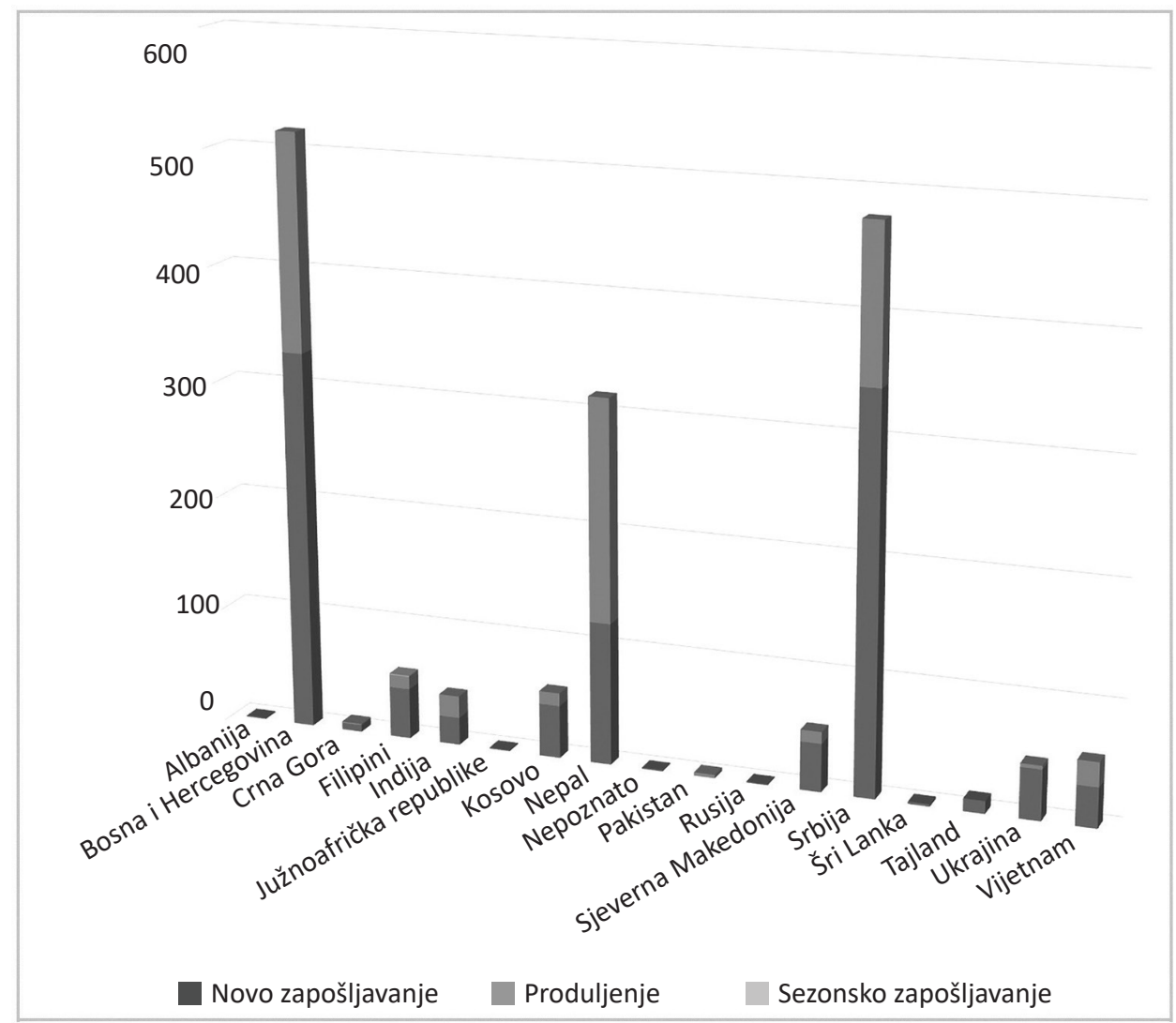

Grafikon 3. Broj stranih radnika u Varaždinskoj županiji prema državljanstvu od 1. siječnja 2020. do 1. srpnja 2020. godini Izvor: vlastita izrada autora prema podacima Policijske uprave Varaždinske 
Grafikonom 4. prikazano je kretanje zaposlenih stranaca prema vrsti djelatnosti u kojoj se zapošljavaju u 2019. godini. Vidljivo je kako se najveći broj stranaca u Varaždinskoj županiji zapošljava u građevinarstvu i to 801 novozaposleni. Odmah nakon građevinarstva slijedi industrija u kojoj se broj novozaposlenih stranaca povećao za 504 osobe te promet i veze u kojima se broj novozaposlenih stranaca povećao za 333. Također u navedene tri djelatnosti zabilježen je najveći broj produljenja zaposlenja stranaca. Što se sezonskog zapošljavanja stranaca u Varaždinskoj županiji tiče, u 2019. godini zabilježeno je samo 15 osoba i to u djelatnosti ugostiteljstva.

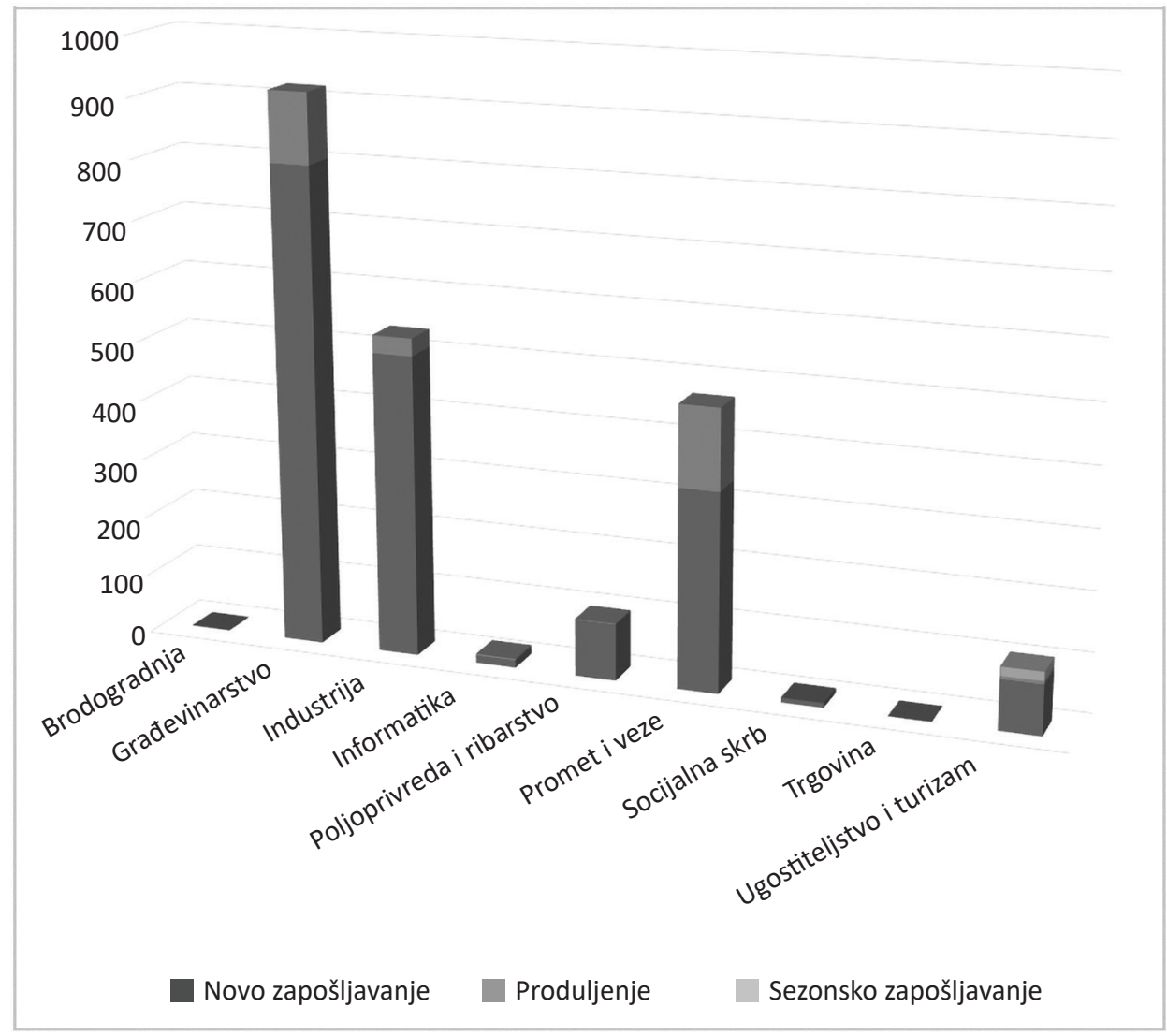

Grafikon 4. Statistički pregled zaposlenih stranaca u Varaždinskoj županiji prema djelatnosti djelatnostima od 1. siječnja 2019. do 31. prosinca 2019. godini Izvor: izrada autora prema podacima Policijske uprave Varaždinske 
Iz grafikona 5., koji prikazuje statistički pregled zaposlenih stranaca u Varaždinskoj županiji prema djelatnosti u 2020. godini, vidljivo je da se u prvoj polovici 2020. godine bilježi porast broja novozaposlenih i produljenja zaposlenja u istim djelatnostima kao i prethodne godine. Ono što je jedina razlika jest da se u prvoj polovici 2020. godine bilježi veći broj produljenja zapošljavanja nego prethodne godine. Brojčano prikazano, u građevinarstvu je novozaposlenih 438 više nego prethodne godine, u industriji 371, a u prometu i vezama 168 više. Što se produljenja zaposlenja tiče, u građevinarstvu je broj stranaca s produljenim zaposlenjem iznosio 190, u industriji 187 te u prometu i vezama 147. Samo jedna strana osoba je u prvoj polovici 2020. godine zaposlena sezonski.

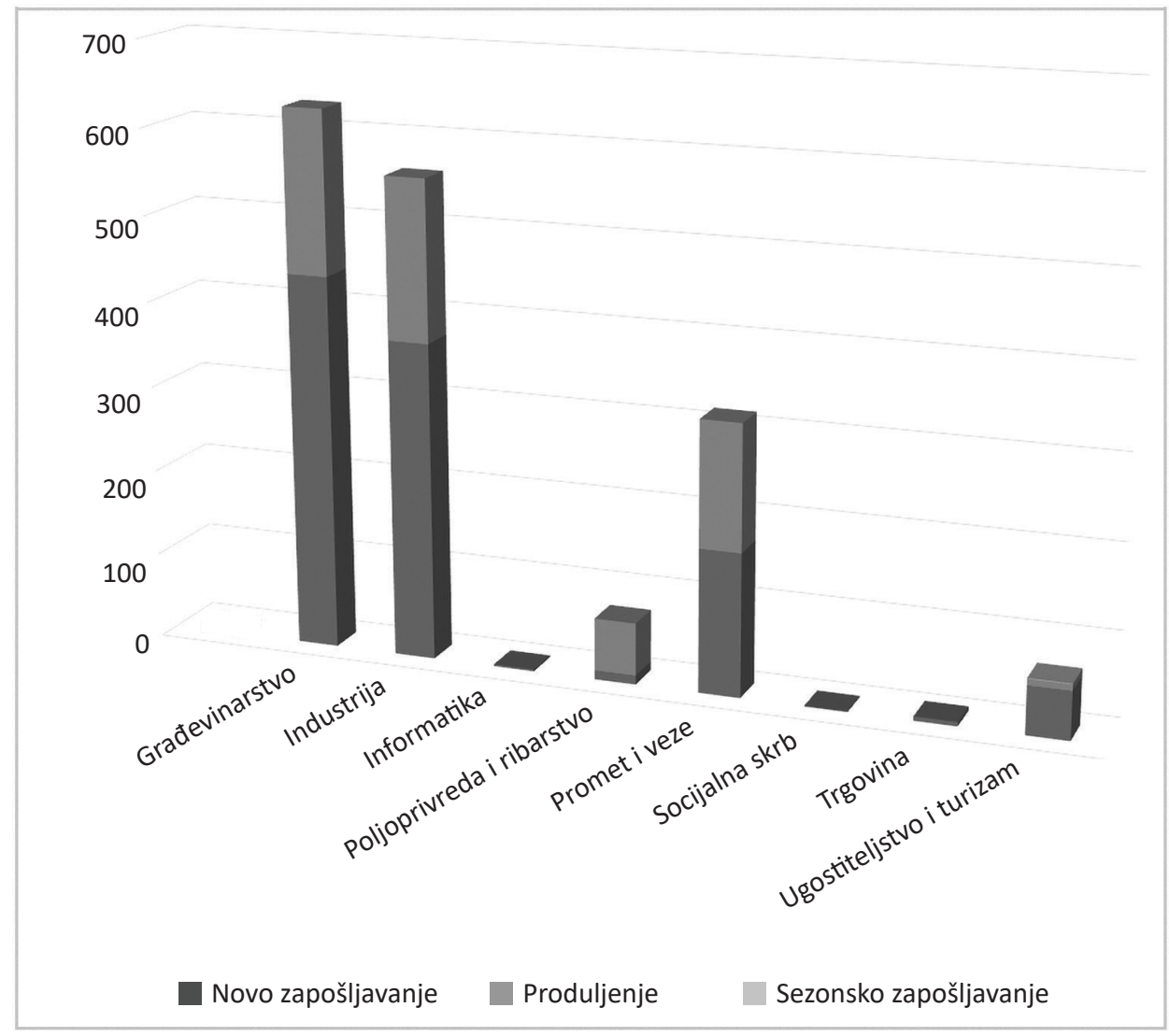

Grafikon 5. Statistički pregled zaposlenih stranaca u Varaždinskoj županiji

prema djelatnostima od 1. siječnja 2020. do 1. srpnja 2020. Izvor: izrada autora prema podacima Policijske uprave Varaždinske 
Kvalitativno istraživanje provedeno je kroz intervju s vodećim osobama u pet poduzeća u Varaždinskoj županiji koja zapošljavaju strane radnike. Odabrana poduzeća posluju u tekstilnoj industriji, prehrambenoj industriji, obućarskoj industriji te farmaceutskoj industriji.

Kako bi se dobili odgovori na istraživačka pitanja, u intervjuu je postavljeno ukupno 8 pitanja:

1. Zašto ste uključili strane radnike u rad svojeg poduzeća?

2. Zadovoljavaju li oni svojom kvalifikacijskom strukom?

3. Jesu li njihove radne navike i znanja u skladu s poslovnim procesima koje obavljaju?

4. Jeste li imali problema s njihovim smještajem? Ako ste imali, na koji način ste ga riješili?

5. Jesu li strani radnici imali problema s uključivanjem u lokalnu zajednicu?

6. Jeste li zadovoljniji stranim radnicima u odnosu na naše radnike?

7. Procjenjujete li da će vam u budućnosti strani radnici trebati više ili manje

8. Jeste li spremni financirati projekt njihove edukacije i inkluzije u društvo?

Kao uvodno, prvo je postavljeno pitanje o državljanstvu stranih radnika koje zapošljavaju. Tri ispitana poslodavca odgovorila su kako većina stranih radnika dolazi iz Nepala, a dva od tri su naglasila kako imaju zaposlene osobe iz Filipina te iz Vijetnama, Indije i Ukrajine. Jedan poslodavac je odgovorio kako njihovi strani radnici dolaze iz Indije, dok je drugi odgovorio kako većina stranih radnika dolazi iz Bosne i Hercegovine.

Gotovo svi intervjuirani imali su isti odgovor na prvo pitanje, naglašavaju kako su strane radnike zaposlili zbog nedostatka domaće radne snage. Također neki su napomenuli kako oglase za posao imaju otvorene kroz cijelu godinu, no nema zainteresiranih. Radne dozvole koje su se nekada morale osigurati, sada se dobivaju automatski putem Hrvatskog zavoda za zapošljavanje (ako ne postoji dovoljno kadra na burzi rada).

Što se tiče kvalifikacijske struke, većina ih ima srednju stručnu spremu, no s obzirom da rade fizičke poslove ne traže se konkretna predznanja u nekom poslu. Također, većina poduzeća osigurala je edukaciju prilikom njihova dolaska na radno mjesto. U navedenom treninzima sudjelovali su voditelji odjela, ali i majstori koji su bili u svojstvu mentora te napominju kako vrlo brzo uče te su unutar pola godine svladali poslove bolje od određenih domaćih radnika. Jedan poslo- 
davac je istaknuo da su prije njihovog dolaska u Republiku Hrvatsku osigurali video filmove u kojima im je prikazano gdje će raditi, koji će biti njihovi poslovi te što se od njih očekuje, jer su htjeli osigurati transparentnost i prikazati im sve što mogu očekivati kako ne bi ništa ostalo ne rečeno. $S$ agencijom preko koje je osiguran njihov dolazak obavili su razgovor u kojem su prezentirali svoju stručnu spremu kako bi poslodavci bili upoznati s kojim kvalifikacijama raspolažu.

Nadalje, što se tiče radnih navika, svi poslodavci su se složili da su stranci jako dobri radnici, izrazito disciplinirani, s visokim radnim moralom te traže raditi prekovremene sate, praznike i blagdane. Svi ispitani koji zapošljavaju Nepalske radnike naglašavaju da su oni ovdje došli zaraditi te da im je cilj kroz nekoliko godina zaraditi za kuću i bicikl u Nepalu zbog visokog siromaštva u toj zemlji pa im nije problem raditi bilo koje radno vrijeme. Vrlo su efikasni i paze da poštuju sva pravila i norme kako ne bi dobili otkaz i kako ih se ne bi poslalo natrag u zemlje iz kojih su došli te kako bi im se produžio ugovor.

Svi poslodavci su bili spremni za dolazak stranih radnika i osigurali su im smještaj. Poslodavci koji zapošljavaju radnike iz dalekih zemalja osigurali su im kuće i stanove koji su ih čekali, dok je jedan poslodavac dao u sklopu tvornice sagraditi mobilne kućice. Poslodavac koji zapošljava radnike iz Bosne i Hercegovine je odgovorio kako također nije imao problem sa smještajem, jer su to radnici koji su smještaj osigurali sami prije nego su došli u Hrvatsku ili su smješteni kod rodbine koja ovdje živi godinama. Jedan poslodavac napominje da su iskoristili Zakonski donesenu odluku od strane Republike Hrvatske u kojoj se trošak najma priznaje ukoliko je isti najam za potrebe smještaja radne snage, ali i da ukoliko netko od stranih radnika odluči pronaći svoj smještaj, snosi trošak najma.

$\mathrm{Na}$ četvrto pitanje o inkluziji u društvo, poslodavci odgovaraju kako nikakvih problema nije bilo. Domaći radnici su odlično prihvatili strane, druže se s njima i privatno i izvan posla, susjedi se na njih ne žale i uredni su. Jako dobro govore engleski jezik, a jedan među njima puno bolje od ostalih. S vremenom svladavaju i osnove hrvatskog jezika te se oko određenih radnih zadataka mogu sporazumjeti na hrvatskom jeziku. U većim poduzećima imaju jednu osobu zaduženu za rad sa strancima, koja ih redovito posjećuje, osigurava im lijekove, komunicira s liječnicima, pa čak i osigurava hranu. Jedan poslodavac je istaknuo kako im je osigurao bicikle kako bi se mogli slobodno i brže kretati. Jedini problem se javio s nepalskim radnicima u jednom poduzeću, no isti je uspješno brzo riješen. Strani radnici poštuju vjerske blagdane koji se obilježavaju u Hrvatskoj, a poslodavci poštuju njihove vjerske blagdane i omogućavaju im tada slobodne dane. 
Zadovoljstvo s domaćim i stranim radnicima je jednako, te sve benefite koje imaju domaći radnici, imaju i strani radnici te ih se ni na koji način ne diskriminira. U budućnosti poslodavci smatraju da će trebati više stranih radnika, no zbog trenutne situacije s pandemijom COVID-19 virusa nisu sigurni hoće li biti dovoljno domaćih radnika na burzi. Ukoliko se nastavi trend kao prethodnih godina, morati morati će zapošljavati više stranih radnika, jer određena poduzeća ne bi mogla odraditi posao i morali bi odbiti određene ugovore i narudžbe.

Svi poslodavci su spremni sufinancirati projekt koji bi omogući dodatnu edukaciju stranim radnicima kako bi se brže i lakše prilagodili poslovima na kojima rade, novim tehnologijama, ali i stjecanja tražene stručne spreme te projekt inkluzije u društvu u kojem bi naučili jezik i kulturu.

\section{ZAKLUČAK}

Zbog velikog broja iseljavanja te samim time i nedostatka domaćeg stanovništva na tržištu radne snage, sve više poslodavaca se odlučuju na zapošljavanje stranih radnika. Još uvijek najveći broj stranih radnika su iz susjednih zemalja Bosne i Hercegovine, Srbije i Sjeverne Makedonije, no zadnje dvije godine bilježi se sve veći broj radnika iz dalekih zemalja kao što su Nepal, Filipin i Vijetnam.

Pandemija uzrokovana COVID-19 virusom dovela je poslodavce u nezavidnu situaciju u kojoj ne znaju kakvo će njihovo poslovanje biti u budućnosti te nisu sigurni hoće li domaći radnici biti dostupni na burzi rada ili će i dalje morati zapošljavati strane radnike. Tri od pet ispitanih poduzeća naglašava da im se posao za vrijeme pandemije povećao te da će dugoročno trebati više stranih radnika kako bi mogli odraditi sav posao. Iz navedenog se može zaključiti da je odgovor na prvo istraživačko pitanja „Postoji li dugoročna potreba za stranim radnicima u Varaždinskoj županiji?" pozitivan i da će dugoročno trebati više stranih radnika.

Također, u kvalitativnom istraživanju je dobiven odgovor na drugo istraživačko pitanje „Koji su problemi uključivanja stranih radnika u poslovne procese?" te treće istraživačko pitanja „Koji su problemi uključivanja stranih radnika u lokalnu zajednicu?". Iz istraživanja je vidljivo da problema sa stranim radnicima nema mnogo, većinom svi uspijevaju riješiti edukaciju interno s vlastitim radnicima koji provode edukacije, a što se tiče jezika, pouzdaju se u barem jednog zaposlenika koji se relativno dobro služi engleskim jezikom. Kulturu poštuju, no prilikom dolaska u zemlju, također ih vlasnici poduzeća s istom upoznavaju kako bi se što bolje uklopili društvo. Kako bi im se ponudila pomoć, tj. kako više poduzeća interno ne bi morali educirati radnike i na taj način gubiti kontinuitet u radu domaćih radnika, postavljeno je pitanje financiranja projekta edukacije i inkluzije stranih radnika u 
društvo. Sva poduzeća su se složila da bi sudjelovala u sufinanciranju navedene edukacije i da bi im takav projekt pomogao kako bi se strani radnici što prije i lakše uklopili u društvo, ali da bi im dobro došlo da je u navedenoj edukaciji moguće stjecanje stručne spreme potrebne za rad u njihovom poduzeću. Važno je prilikom provedbe takvog projekta razlikovati inkluziju visokoobrazovanih stručnjaka od osoba sa srednjom stručnom spremom te primijeniti različiti pristup.

Percepcija o zapošljavanju stranih radnika ovisi o samim ljudima te su na početku većina njih imali odbojnost, no kako su zbog nedostatka kadra bili prisiljeni zapošljavati strane radnike i kako su se dokazali kao dobri i vrijedni radnici, percepcija o stranim radnicima se mijenja.

Važno je napomenuti kako država za strane radnike koji dolaze iz Nepala, Vijetnama, Filipina i sl. zemalja koja su tek nedavno počela činiti radnu snagu u Republici Hrvatskoj, ne predstavlja nikakav trošak za Republiku Hrvatsku već upravo suprotno. Za navedene radnike se plaća porez, prirez, mirovinsko i socijalno, a mirovina za takve radnike nema. Upravo da nije bilo tih radnika, proizvodnja u nekim poduzećima bi stala te se ne bi navedeno uplaćivalo i na taj način punila državna blagajna. Potrebno je strogo razgraničiti strane radnike koji u zadnje vrijeme ulaze u države Europske unije bez putovnice i ostalih dokumenata, nasilno, od radnika koji su zaposleni redovitim putem, dolaze s papirima, uredno su prijavljeni, kontinuirano rade i došli su putem raznih agencija legalno, a koji se u ovom radu proučavaju.

\section{DOPRINOS I DALJNJA ISTRAŽIVANJA}

Do sada provedena istraživanja ne analiziraju konkretno Varaždinsku županiju kao županiju koja zapošljava najveći udio stranih radnika u Republici Hrvatskoj te se trenutno suočava s velikim manjkom radnika. Navedenim istraživanjem htjelo se pokazati kako domaća radna snaga ne mora strahovati za svoja radna mjesta, ali i analizirati koji profil radnika dolazi te kako su poslodavci zadovoljni s istima. Tako đer, s obzirom na veliki broj iseljavanja domaće radne snage, velika je mogućnost da će i u budućnosti postojati potreba za stranim radnicima te je vidljivo kako navedena poduzeća, ukoliko će postojati potreba, i dalje planiraju uvoziti radnu snagu. Rezultati istraživanja daju smjernice vodećim osobama Varaždinske županije kako bi potaknuli prilagodbu stranih radnika na našu kulturu i život u Varaždinskoj županiji.

U budućnosti bi trebalo provesti kvalitativno istraživanje kroz intervjue sa stranim radnicima te usporediti rezultate dobivene intervjuima sa vodećim oso- 
bama poduzećima u kojima su zaposleni. Također bi se takvim istraživanjem mogla vidjeti namjera stranih radnika za duljim ostankom u Varaždinskoj županiji i njihova zainteresiranost za sudjelovanje u projektima inkluzije u društvo. Rezultati dobiveni takvim istraživanjem opravdali bi projekte koje bi Varaždinska županija mogla provesti njihovu inkluziju, ali bi i dala informacije o zadovoljstvu stranih radnika kako poslodavcima tako i životom u Varaždinskoj županiji. Osim proširivanja ovog istraživanja, a sve većim dolaskom stranih radnika i u ostale županije, istraživanje bi se moglo proširiti na Republiku Hrvatsku, kroz koje bi se ispitali razlozi dolaska stranih radnika u Republiku Hrvatsku i njihovo zadovoljstvo životom ovdje, ali i namjeru odlaska u druge zemlje Europske unije ili povratka u svoju državu.

\section{LITERATURA}

1/ Đuro BENIĆ, Uvod u ekonomiju, Školska knjiga, 2011., Zagreb.

2/ S. BOŽIĆ, B. KUZMANOVIĆ, V. BARADA (2013) Strani radnici u Hrvatskoj: porijeklo, status, orijentacije. Migracijske i etničke teme, 293 ). Dostupno dana 2.11.2020 na: https://hrcak.srce.hr/index.php?show=clanak\&id_clanak_jezik=174184.

3/ J. ČAČIĆ-KUMPES, S. GREGUROVIĆ i J. KUMPES (2012). 'Migracija, integracija i stavovi prema imigrantima u Hrvatskoj', Revija za sociologiju, 42(3), str. 305336. Dostupno dana 9.11.2020. na: https://doi.org/10.5613/rzs.42.3.3.

4/ D. FERJANIĆ HODAK, O. KESAR, I. MATEČIĆ (2019) The influence of foreign labour force on service provision and hotel guests' experience - the case of coastal Croatia. Tourism in Southern and Eastern Europe, Vol. 5, pp. 275-289.

5/ I. KRIŠTO, C. KOVAČ, A. ŠIJAKOVIĆ (2018.) Sigurnost i zaštita zdravlja stranih radnika - uloga stručnjaka zaštite na radu .13th INTERNATIONAL CONFERENCE MANAGEMENT AND SAFETY, CONFERENCE THEME: PROJECT MANAGEMENT AND SAFETY PROGRAM CYCLE: MODERN MANAGEMENT CONCEPTS AND SAFETY / Vesna Nikolić, Chair of the International Program Committee Members of the International Program Committee (ur.).

Čakovec, Croatia: The European Society of Safety Engineers. 34,12.

6/ Lider media. CMS upozorava na teškoće u zapošljavanju migranata u Hrvatskoj. Dostupno dana 2.11.2020. na: https://lider.media/aktualno/cms-upozorava-na-teskoce-u-zaposljavanju-migranata-u-hrvatskoj-33100. 
7/ Ministarstvo unutarnjih poslova. Statistika. Iskorištenost godišnje kvote za 2020. na dan 27.11.2020. Dostupno dana 28.11.2020. na: https://mup.gov. $\mathrm{hr} /$ serDocsImages/statistika/2020/Kvote/ISKORISTENOST-GODISNJE-KVOTE-ZA-2020-NA-DAN-27-11-2020.pdf.

8/ Novi list. Nikad manje stranih radnika u Hrvatskoj: Neiskorištena 53.931 radna dozvola. Dostupno dana 5.11.2020. na: https://www.novilist.hr/ novosti/hrvatska/nikad-manje-stranih-radnika-u-hrvatskoj-neiskoristena-53-931-radna-dozvola/?meta_refresh=true.

9/ Središnji državni portal. Moja uprava. Pravna država i sigurnost. Strani radnici u RH. Rad stranaca. Dostupno dana 8.11.2020. na: https://gov.hr/moja-uprava/pravna-drzava-i-sigurnost/strani-drzavljani-u-rh/rad-stranaca/1724.

10/ A. ŠIJAKOVIĆ (2019) Zaštita na radu i strani radnici u RH. Sigurnost 61 (4). 391-394.

11/ Zakon o radu. NN 93/14, 127/17, 98/19. Dostupno dana 5.11.2020. na: https://www.zakon.hr/z/307/Zakon-o-radu.

\section{SUMMARY}

\section{THE IMPORTANCE OF FOREIGN WORKERS FOR THE DEVELOPMENT OF THE ECONOMY IN VARAŽDIN COUNTY}

Increased migration to the Republic of Croatia increases the number of foreign workers available on the labor market. In recent years, Varaždin County has recorded a significant growth of foreign workers in various industries. The secondary research conducted an analysis of the number of foreign workers in 2019 and 2020 who are currently registered in the Varaždin County. Conducted interviews with companies operating in the food, textile and pharmaceutical industries collected qualitative data on the importance of foreign workers both for the companies themselves and for the county's economy. The research provides answers to questions about the long-term need for foreign workers, their involvement in business processes, possible barriers they face (linguistic and technological), but also sees the problem of their inclusion in the local community in terms of prejudice, culture and language.

Key Words: foreign workers; inclusion in society; labor force; Varaždin County. 